第35回日本輸血学会総会

総会長講演

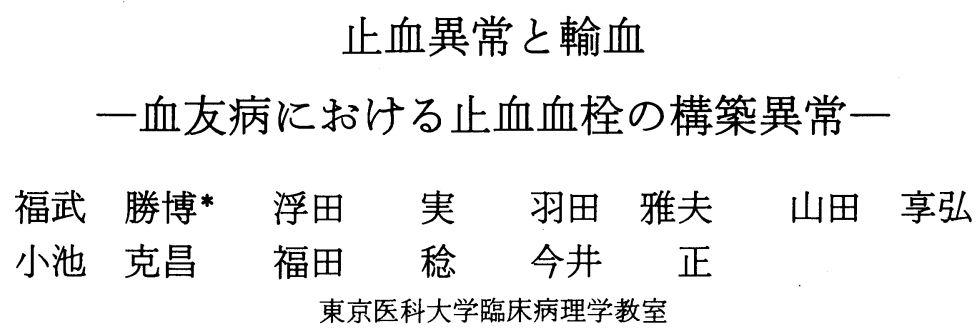

\title{
BLOOD TRANSFUSION AND HEMOSTATIC ABNORMALITIES WITH SPECIAL REFERENCE TO ABNORMAL CONSTITUTION OF HEMOSTATIC PLUG IN HEMOPHILIA
}

\author{
Katsuhiro Fukutake*, Minoru Ukita, Masao Hada, Takahiro Yamada, Katumasa Koike, \\ Minoru Fukuda and Tadashi Imai \\ Department of Clinical Pathology, Tokyo Medical College \\ *Speaker, President of the 35th Annual Meeting of JSBT (1987)
}

The constitutional nature of hemostatic plug is important for hemostasis, because hemostatic plug might be functioning a direct role to cease bleeding at the site of hemorrhage. Therefore, the structual abnormalities of the plug in patients with hemophilia have been reported recently by us and others. However, there are many unknown mechanisms to produce the qualitative abnormalities of plug structure, which might be constructed mainly fibrin-closslinked mass and appregated platelets.

In this paper, the authors observed the time course on the release of factor XIII a subunit from the platelet aggregates to the factor XIII deficient plasma by the use of our ELISA technique with polyclonal antibody against factor XIII a subunit, and it was shown a positive relationship between the release phenomenon of platelet factor XIII and the autolytic destruction process of platelet aggregates, and the 50\% release of factor XIII from platelet aggregates was measured about $4 \mathrm{hrs}$ after platelet aggregation induced by ADP or thrombin.

In the experiments of hemophilia A cases the amount of crosslinked von Willebrand factor and fibronectin to fibrin clot tended to increase but the crosslinkage of $\alpha_{2}$ plasmin inhibitor to fibrin showed a decreasing tendency in the fibrin clot obtained from the recalicified patient plasma mixed with ${ }^{125}$ I-labeled $\alpha_{2}$ plasmin inhibitor. Those data might indicate the reason for rapid fibrinolysis by urokinase added on the recalicified clot from the plasma collected before and after the administration of factor VIII reparation to hemophiliacs and also the reason for low values of the maxmum amplitude in thrombelastgraphy performed on nine patients with hemophilia A.

According to the results above mentioned it might be suggested that the qualitative abnormalities of crosslinked fibrin structure of the hemostatic plug in the patients with hemophilia might effect on the disfunction of the plug, but the reaction mechanisms inducing such abnormal changes of the clot structure are still not elucidated in detail. However, the prolongation of blood clotting time due to low activation of thrombin with untimely supply of platelet factor XIII might be possible as a reacting condition for this abnormal distribution of crosslinkage.

はじめに

止血異常は主に血小板や血漿凝固因子の質的量的な 異常に起因した病態であり, 臨床的には多様な出血症 状を呈する。しかし，疾病により可成り特徵的な出血
所見を認めるものもある. 例へば, 先天性 XIII 因子欠 乏症では打撲後出血と共に脳内出血の頻度は極めて高 く, 吾々の経験した 3 症例とも脳内出血を経験してい る。また，血友病においては関節内出血の頻度の高い 


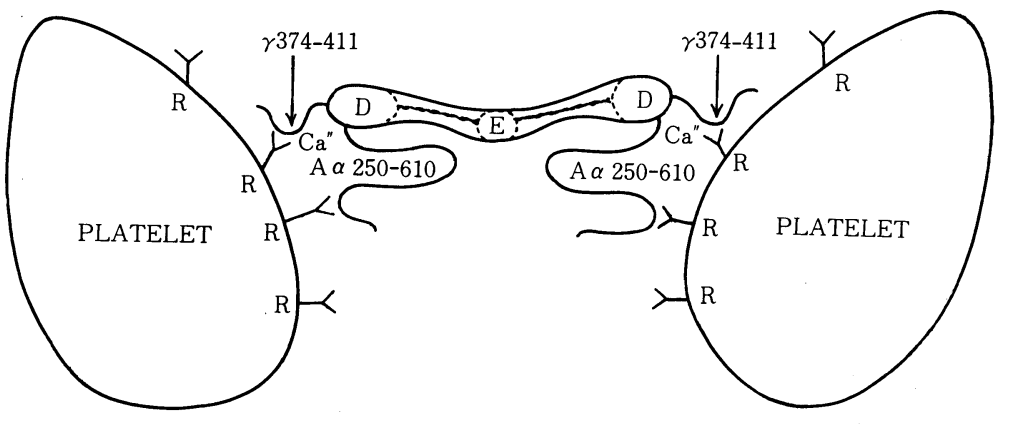

図 1 血小板凝集に括けるフィブリノゲン架橋（Niewiarowskiら，1986）

ことは血友病関節症として知られている。

正常人においては血管壁が損傷をうけると，出血局 所にまず血小板血栓を作り，ついで凝固血栓ができて 止血血栓が完成され，止血は完了寸る．その後，線維 素溶解現像を主体とした血栓溶解が括こり，血管壁の 正常化への修復がみられる。

損傷局所における血小板血栓の形成は損傷直後に始 り, 通常は数分内に終了して凝固血栓へ移行する．凝 固血栓の基本はフィブリン線維により構築され，その 構造の強勒性や創傷治瘾にたいする機能はフィブリン 線維の重合状態に依存している。フィブリン重合は XIII 因子に上る交叉架橋 crosslinkage を介して展開 されるが，フィブリン分子同志によって架橋重合と フィブロネクチン, von Willebrand 因子, $\alpha_{2}$ プラスミ ン・インヒビターあるいはコラゲン等々の関連物質と フィブリンとの架橋重合の様々な組み合せが止血血栓 としての機能に影響する。

\section{1. 血小板と止血血栓}

a. 血小板と凝固因子の相関

出血局所で血小板は活性化され, 血小板内カルシウ ムを増加すると共に二次凝集に必要な物質を生成し て，血小板同志の凝集を起し，von Willebrand 因子を 介して組織に粘着する. 血小板凝集に当ってはフィブ リノゲン D ドメインの $\gamma$ 鎖と $\alpha$ 鎖 $\mathrm{C}$ 末端部位が, カ ルシゥムの共存のもとで血小板のリセプターすなわち 血小板膜の糖蛋白 $\mathrm{GP} \mathrm{I}_{\mathrm{b}}$ と $\mathrm{GP}_{\mathrm{I}}-\mathrm{III}_{\mathrm{a}}$ 複合体と結合し て，2 個の血小板の間にフィブリノゲン 1 分子の架橋 が行なわれて, 血小板凝集が起こる(図 1, Niewiarowski ら, 1983)1 ${ }^{1}$.

また, 出血局所での血小板と組織の結合は von Willbrand 因子を介して行なわれるが血小板の活性化に よって露出された血小板膜の GP $\mathrm{I}_{\mathrm{b}}$ は von Willebrand 因子 $\mathrm{N}$ 末端とのリ七プターとなり，血小板膜

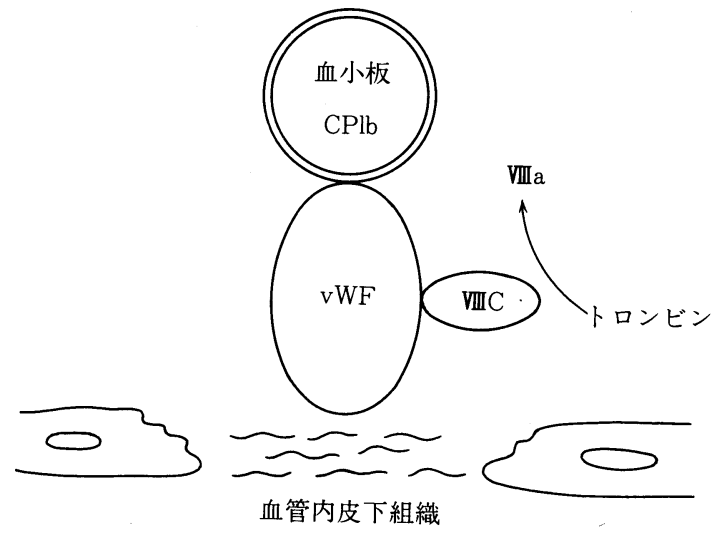

図 2 VIII因子/vWF複合体と止血（L. Hoyer， 1987）

GP $\mathrm{II}_{\mathrm{b}}-\mathrm{III}_{\mathrm{a}}$ 複合体は von Willebnand 因子 $\mathrm{C}$ 末端のレ セプターとなると言われている. 元来, von Willebrand 因子はVIII因子と複合体を作って血漿中に存在し ているために, von Willebrand 因子が出血局所で血小 板と組織の間に介入し，そのために VIII-von Willebrand 因子複合体が出血局所に濃縮固定される。その 局所でVIII因子が活性化されて凝固促進作用を発揮す る. VIII因子の血中濃度が $100 \mathrm{ng} / \mathrm{m} l$ と凝固因子中最も 微量なものであるだけに，V四因子の出血局所への濃縮 化といら意味が合理的なメカニズムである（図 2 ,

Hoyer ら, 1987) ${ }^{2)}$. これらの血小板または血小板血栓 の組織への結合の仕組は血小板血栓を組織に定着し, 血流に拮抗して局所に固定される安定した止血血栓を 形成する上に必要な機構でもある。

しかし, 血小板の側から血漿凝固因子による凝血を 補助する働きを示すメカニズムも存在している，血小 板よりの放出物質のらちセロトニンはその血管収縮作 用によって間接的に止血機構に関与するし，血小板第 3 因子はリン脂質の膜面において $\gamma$-カルボキシグル 


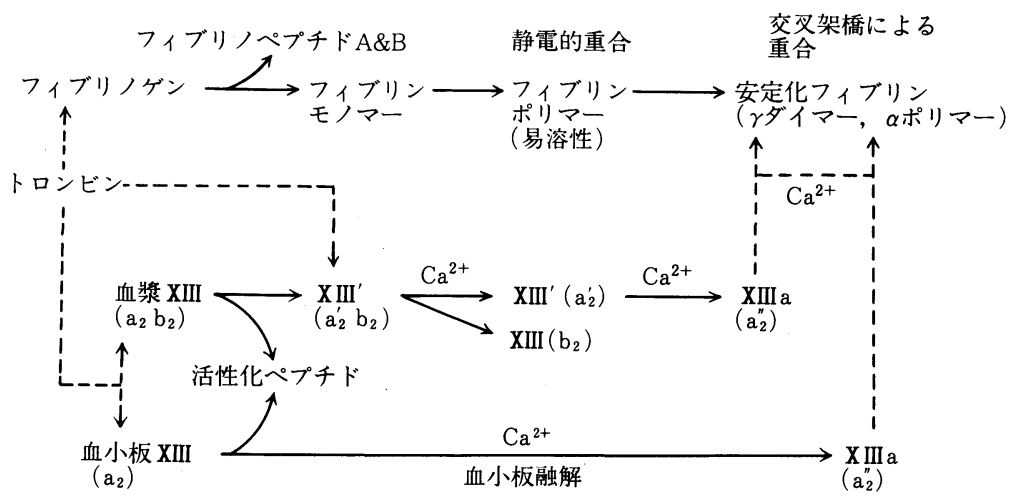

（注）1）（）内はXIII因子のSubunit a，bの変化

2) —は活性化方向

3）…は酵素作用を示す

4）XIII aは活性基の露出した活性化 X III因子

図 3 フィブリン重合に対応するXIII因子の活性化

タミン酸を介して凝固反応を促進し, 血小板第 4 因子 はその抗へパリン作用によってへパリンの凝固阻止反 応に拮抗して血液凝固を促進する。また，血小板内に はカテプシン, エラスターゼなどの血夜凝固, 線溶系 に有効であると思われる諸種の酵素を内臓しており， さらにはフィブリノゲン，V因子，VIII因子などが血小 板に吸着されており局所の凝固反応に有効である。更 に血液凝固反応には直接的な影響はないが，止血血栓 内に拈けるフィブリン重合に重要な酵素であるXIII 因子が a subunit 単独の dimer として血小板内に存在 している.

これらの止血血栓の生成に有効な血小板内物質は止 血過程に打いて止血局所に供給されなければならな い.その供給経路は 3 つに要約されると思われる。す なわち，1）血小板の濃縮顆粒や $\alpha$ 顆粒に内臟されて いる物質は血小板の活性化，凝集に伴って開放小管系 を介して細胞外へ能動的に放出される。ついで，2）血 小板第 3 因子は血小板の活性化によって血小板膜へ近 接して血小板第 3 因子能を増幅し，その後にこの部か ら放出される。さらに，3）XIII 因子のように能動的な 放出機構をもたない物質はおそらく経時的に血小板血 栓の内部で血小板の自家融解が起り, 血小板に内蔵さ れている有効物質が細胞外に放出される（図 3 ）。

b. 血小板 XIII 因子の放出機転

吾々は抗 XIII 因子 a-subunit ポリクロナル抗体を 用いて，XIII 因子 a-subunit を測定する ELISA 法を 開発し (小池, 1987) $)^{3)}$, 正常血小板と先天性 XIII 因子

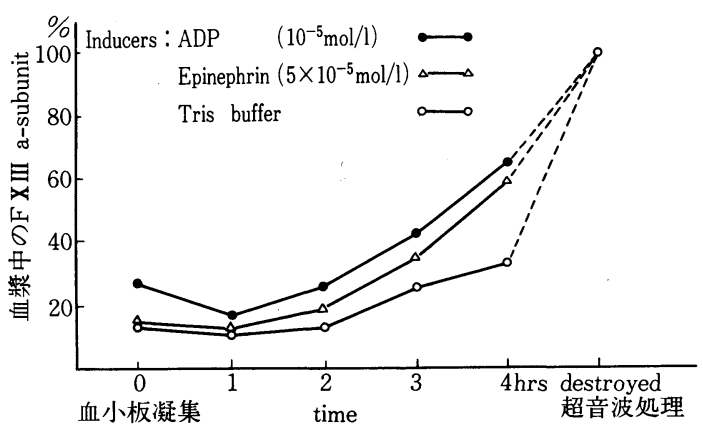

図 4 血小板XIII-a subunitの血小板凝集後の血漿へ の出現

欠乏血漿を混合して多血小板血漿を合成して，これに $\mathrm{ADP}$, トロンビンを加えて血小板凝集を起こし, 経時 的に血墏中に血小板凝集塊から放出されてくるXIII

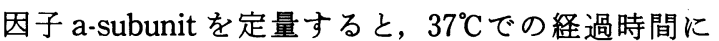
従って血漿に出現する a-subunit 量は增加し, 凝集 4 時間後の検体では，超音波破砕による a-subunit 量を 100\%とすると，その約 $50 \%$ が血墏中に認められるに 至った，対照の血小板凝集誘発物質を添加しない場合 の变性血小板打よび遠心時の自然凝集血小板塊よりの 放出は約30\%弱であった（図 4).

この所見を透過電子顕微鏡写真ネガティブ染色 12,000 倍で観察するとトロンビン, ADP 添加直後に比 して凝集 4 時間後の血小板凝集塊中では血小板はその 数を減少すると共に血小板変性物質と思われるものに よって視野の大部分が占められている(写真 $1,2,3$ ， 


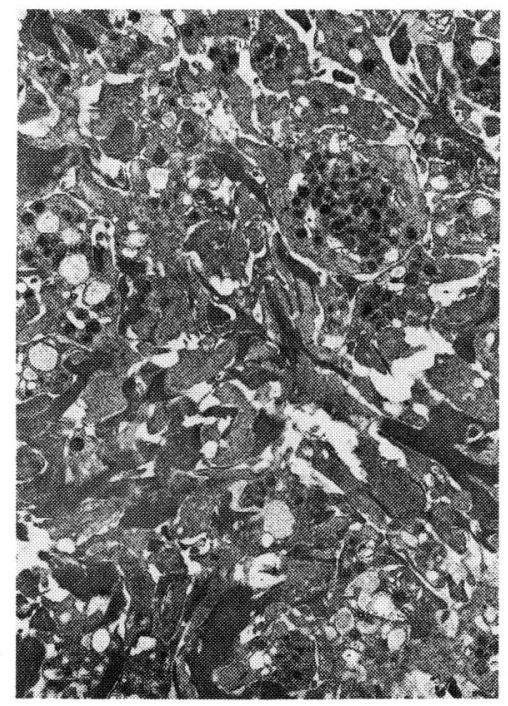

写真 1 トロンビンによる血小板凝集 4 時間後の電顕 像

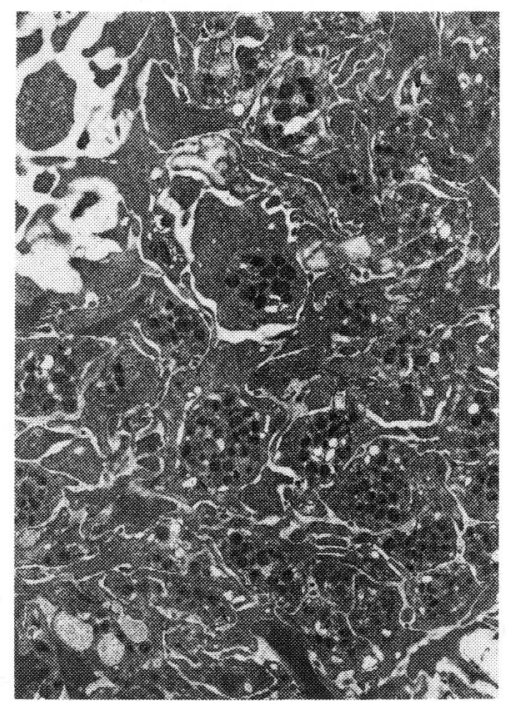

写真 2 トロンビンによる血小板凝集直後の電顕像

4 ）。また，血小板凝集誘発物質を加えない対照実験で は遠心時に一部自然凝集を示したが，多血小板血漿の 遠心沈渣は 4 時間後において血小板の変性は進んでい るが，血小板数には著変はなく，可成りの血小板の残 存がみられた。

血小板凝集時にみられる通常の能動的放出反応は凝 集後数分以内に起るものであるが，XIII 因子の血小板 融解によると思われる放出は数時間を要する反応であ ると思われた。このよらな長時間をかけての XIII 因子

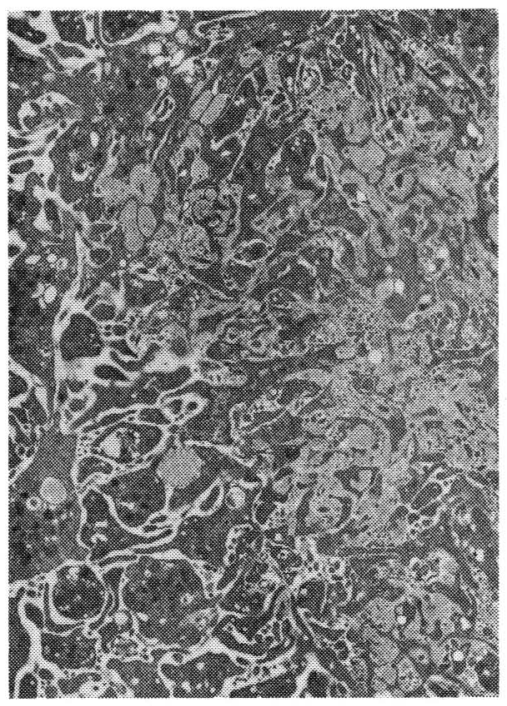

写真 $3 \mathrm{ADP}$ にる血小板凝集 4 時間後の電顕像

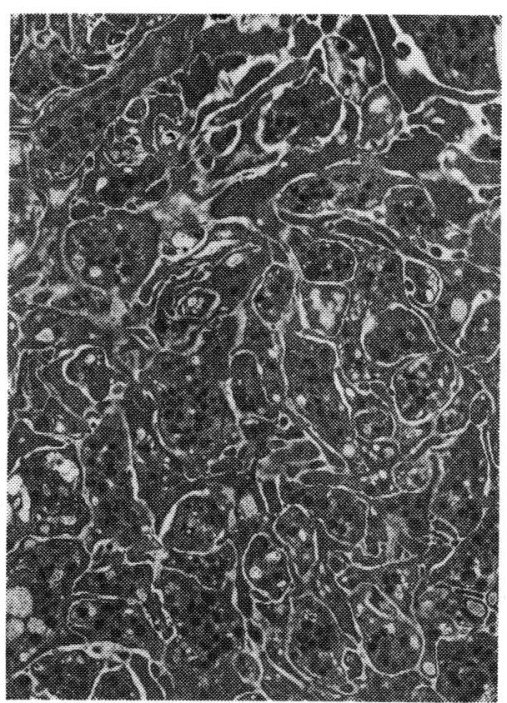

写真 $4 \mathrm{ADP}$ にる血小板凝集直後の電顕像

放出反応に対応する止血血栓内での反応は控そらく フィブリン重合のらち $\alpha$ ポリマーの重合に関連する ものと思われる。

ちなみに，純化フィブリノゲンをトロンビン拉よび 活性化 XIII 因子の共存下で, 生成したフィブリン塊を 還元 SDS ポリアクリラマイドゲル電気泳動によって 経時的に観察すると, $\gamma$-ダイマーは凝固10分後のフィ ブリン塊中に充分量が出来ているのに対して， $\alpha$-ポリ マーの形成は凝固 1 時間後においても生成途中である 


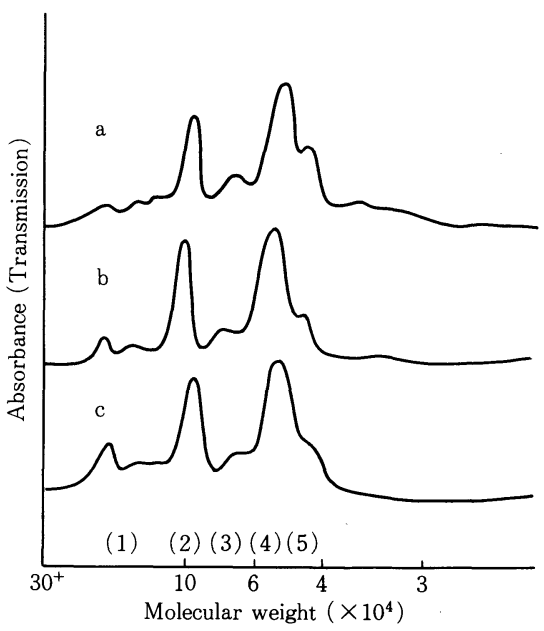

（注） a. incubation for $10 \mathrm{~min}$; b. incubation for $30 \mathrm{~min}$; c. incubation for $60 \mathrm{~min}$.

(1) $\alpha$-polymer ; (2) $\gamma$-dimer ; (3) $\alpha$-chain ;

(4) $\beta$-chain; (5) $\gamma$-chain.

図 5 トロンビン, 活性化XIII因子の共存下での>ィ ブリン塊の還元SDSポリアクリラマイドゲル電気 泳動像

ことが示され，その完成には長時間を要するものと思 われた(図 5$)^{4)}$ 。 また，吾々の蛇毒による実験 $(1986)^{4)}$ やBrombäck ら (1983)5)の報告によっても Batroxobin 蛇毒は極めて小量の XIII 因子の活性化を起すに 過ぎないが，蛇毒添加によって生ずるフィブリン塊に は $\gamma$-ダイマーのみを認め, $\alpha$-ポリマーを殆んど認めな い. 上述の実験を併せると, $\gamma$-ダイマーは少量の活性 化 XIII 因子によって迅速に生成されるが, $\alpha$-ポリマー の生成には大量の活性化 XIII 因子と長時間にわたる 生成時間を必要とする，その故に長時間を要する血小 板 XIII 因子の放出に対して $\alpha$-ポリマーの生成が対応 していると示唆される.

\section{2. 凝固異常とフィブリン重合}

a. フィブリンの静電的重合と阻害

フィブリンの重合はXIII 因子による交叉架橋が行 なわれる前の段階で, 静電的な電位の变化からフィブ リン・モノマーの 2 個または 3 個の分子が互に接合す る過程がある。フィブリノゲンからトロンビンによっ て陰性荷電をもつフィブリノペプチド A と B が分離 されると, その結果, 生成されたフィブリン・モノマー

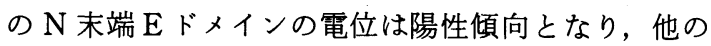
フィブリン分子またはフィブリノゲン分子の D ドメ イン陰性荷電部位と互に向き合った形で接合し易くな
る.その結果, 静電的重合としての $\mathrm{DD} / \mathrm{E}$ 複合体が形 成されて,ついでXIII 因子による架橋のためのイソペ プチド反応が続行する。

フィブリン・モノマーの静電的重合に関連している 部位は陽性傾向となった Eドメインと他のフィブリ ン・モノマー分子の陰性荷電を示す D ドメインの 2 個 所であるから, 重合阻害の起る部位も E あるいは D ド メイン何れでも起り得ることになる。例えば, Eドメイ ン中の成分に類似した構造をもつ合成低分子ペプチド Gly-Pro-Arg'-Pro は Doolittle ら (1980) ${ }^{7}$ とよって述 ベられているよらにフィブリン重合を阻害するが，そ の機序は，この陽性荷電を示す低分子ペプチドがフィ ブリン・モノマーの陰性荷電 D ドメインと親和性を示 すために, フィブリン・モノマー同志の静電的重合に 競合してその重合を阻止する作用を示すためであっ て,フィブリン重合の $\mathrm{E}$ 成分による阻止といえる。 た, フィブリノゲンの線溶分解物 FgDP.Y 分画は 2 量 体フィブリノゲンから線溶酵素プラスミンによって 1 つの Dドメインを失った分解物であるが，フィブリ

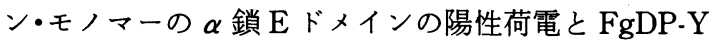
の陰性荷電 $\gamma$ 鎖 D ドメインが親和性を示して静電的 接合をするために, フィブリン・モノマー同志の接合 と FgDP.Y が競合して，フィブリン・モノマー同志の 静電的重合を阻害する。この場合はフィブリン重合の D 成分による阻止といえる（図 6 ）.

これらの重合阻害によってフィブリン・モノマーは 連続する重合物を作ることは出来ないので可溶性とな り, 所謂可溶性フィブリン・モノマー複合体 soluble fibrin-monomer complex (SFMC) と言われる形を取 ることになるし，その結果として，後属して起るはず の XIII 因子による交叉架橋すなわちイソ-ペプチド結 合によるフィブリン重合の形成も二次的に阻害をうけ ることになる.

また, 吾々の実験によると, FgDP.Y 分画のフィブ リンの重合阻害の発現には分子量500以下の重炭酸イ オン $\left(\mathrm{HCO}_{3}^{-}\right)$やクレアチニン, クレアチンなどの陰 性荷電の低分子電解質の共存が重要であって, おそら くFgDP 自身の高次構造に影響するものと思われる （表 1).ちなみに，クレアチニン類似物質であるが, 陽性荷電をもつグアニヂンはFgDP の抗トロンビン 作用（抗重合作用）を阻止し，強い陽性傾向を示す硫 酸プロタミンの添加はFgDPによって重合阻害をう けて SFMC 状態にあるフィブリン・モノマーから，そ の阻害をはずしてフィブリン重合物を速やかに生成す 
E成分による阻害

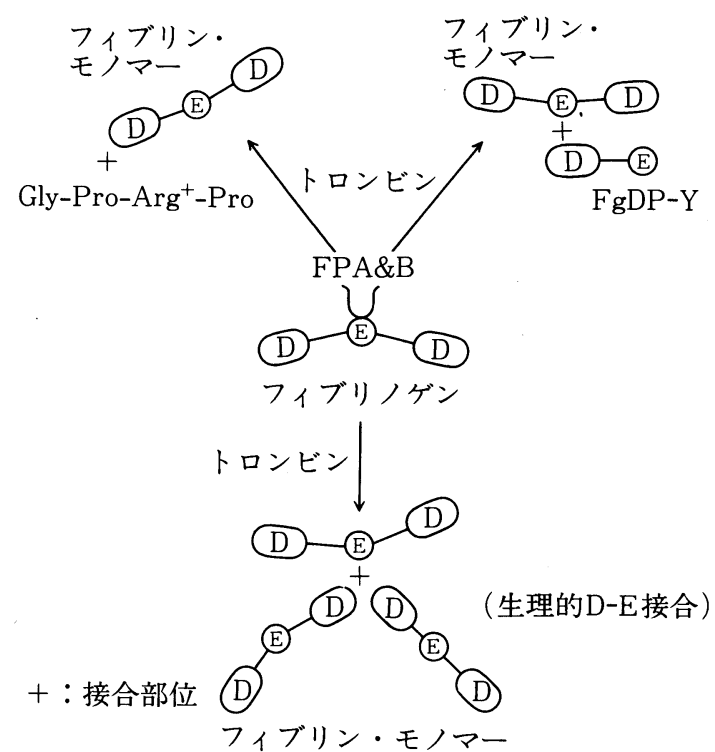

困 6 静電的フィブリン・モノマー重合の阻害

表 1 Fg DP.Y の抗トロンビン作用に及ぼすグフニ ヂン関連化合物の影響

\begin{tabular}{|c|c|c|c|}
\hline 実 & 験 & 系 & $\begin{array}{c}\text { 凝固時間 } \\
(\mathrm{sec})\end{array}$ \\
\hline \multicolumn{3}{|c|}{ 血漿＋生食水 +生食水十トロンビン } & 19 \\
\hline \multicolumn{3}{|c|}{ 血漿＋Fg DP+生食水+トロンビン } & 55 \\
\hline \multicolumn{3}{|c|}{ 血漿＋生食水＋クレフチニン十トロンビン } & 24 \\
\hline \multicolumn{3}{|c|}{ 血漿＋Fg DP+クレアチニントトロンビン } & $180>$ \\
\hline \multicolumn{3}{|c|}{ 血漿＋生食水＋クレアチン+トロンビン } & 23 \\
\hline \multicolumn{3}{|c|}{ 血漿+Fg DP+クレアチン+トロンビン } & $180>$ \\
\hline \multicolumn{3}{|c|}{ 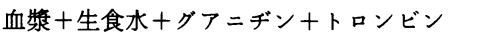 } & 26 \\
\hline \multicolumn{3}{|c|}{ 血漿 +Fg DP+グアニヂン+トロンビン } & 56 \\
\hline
\end{tabular}

る働きを示す (福田ら, 1986) $)^{8}$.

b. フィブリン重合とXIII 因子の活性化

フィブリン・モノマーの静電的重合に阻害のかから ない生理的な状態では, フィブリン・モノマーの分子 間で夫々の $\gamma$ 鎖 $\mathrm{D}$ ドメインと $\alpha$ 鎖 $\mathrm{E}$ ドメインの間で $\mathrm{DD} / \mathrm{E}$ 接合体の形成が静電的に起こり，ついで活性化 されたXIIIa 因子とカルシウムが介入して $\gamma$-dimer から $\boldsymbol{\alpha}$-polymer への交叉架橋反応が進行し, その重合 化が充実するに従って安定化フィブリンが形成され る. その際, 活性化 XIIIa 因子の酵素作用はトランス グルタミナーゼ作用であって, フィブリン分子内のグ ルタミンと他のフィブリン分子内のリジンとの間で交 叉した形でイソペプチド結合を行う。そして $\gamma$-dimer
の生成は即時的で, $\gamma$ 鎖 C 末端の $\operatorname{Lys}(6)$ と glu (14) の間で架橋し, $\alpha$-polymer の生成は経時的で, $\alpha$ 鎖 glu (326，366）と Lys $(508 ， 584)$ の間で架橋する(Scherga 5, 1984) ${ }^{6}$.

XIII 因子がフィブリンの交叉架橋反応に参入する ためには, まず XIII 因子が活性化されなければならな い.一般に認められているXIII 因子活性化の機序は, 血漿 XIII 因子が a-subunit と b-subunit から構成され て拉り， $\mathrm{a}_{2} \mathrm{~b}_{2}$ 複合体を形成しているが，トロンビンによ り活性化ペプチドを a-subunit から遊離して, XIII 因 子 $\mathrm{a}_{2} \mathrm{~b}_{2}$ は $\mathrm{a}_{2}{ }_{2} \mathrm{~b}_{2}$ となり, ついでカルシウムにより subunit が個々に分離して $\mathrm{a}^{\prime}{ }_{2}$-subunit となり, この時点で高次構造の变化が起こり $\mathrm{a}^{\prime}{ }_{2}$ subunit から活性基が露出して活性化 XIII 因子 $\mathrm{a}^{\prime \prime}{ }_{2}$ subunitになると言われている。

しかし，吾々が開発したXIII 因子の a-subunit と b-subunitに対する抗体を用いた ELISA sandwich

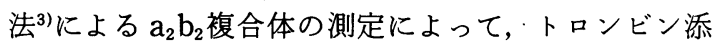
加後の脱フィブリノゲン EDTA 加血漿中における $\mathrm{a}_{2}$ $\mathrm{b}_{2}$ 複合体の消長を観察すると, トロンビンのみの添加 によって血獎中の $\mathrm{a}_{2} \mathrm{~b}_{2}$ 複合体はトロンビン濃度に依 存して減量を示した(図 7 ). またクェン酸塩加正常血 漿にトロンビン, カルシウムを同時に添加すると, 血 漿中の $\mathrm{a}_{2} \mathrm{~b}_{2}$ 複合体は極めて迅速に減少し, 複合体は完 全にa-subunit とb-subunit に解離することが示され た(図 8 ).これらの成績から $\mathrm{a}_{2} \mathrm{~b}_{2}$ 複合体の解離反応は トロンビン添加のみで進行しらるが, カルシウムの共 存はその反応速度を著しく促進するものと思われた。

この際, トロンビンは $\mathrm{a}_{2} \mathrm{~b}_{2}$ 複合体を解離するのみで なく, a-subunit から活性化ペプチドを遊離して $\mathrm{a}^{\prime}$. subunit とし, さらにカルシウムは $\mathrm{a}^{\prime}$-subunit の高次 構造を变化してトランスグルタミナーゼとしての活性 基 $\mathrm{a}^{\prime \prime}$-subunit を露出する。 その結果, フィブリン・モ ノマーは交叉架橋して $\gamma$-ダィマー,ついで $\alpha$-ポリ マーを生成して安定化フィブリンを形成する。そして, フィブリン網を基本とする止血血栓も安定化し完成さ れる。

しかし，XIIIa 因子による交叉架橋の対象となる基 質は単にフィブリン・モノマー同志のみではなく, フィ ブリン・モノマーの $\alpha$ 鎖 C 末端の Lys 518 584に対 してフィブロネクチン, $\alpha_{2} \mathrm{PI}\left(\alpha_{2}\right.$ プラスミン・インヒ ビター), von Willebrand 因子, コラゲン,トロンボ スポンジン, ミオシン, アクチンなどの $\mathrm{N}$ 末端 glu の 架橋することが知られている(図 9).このようにフィ 


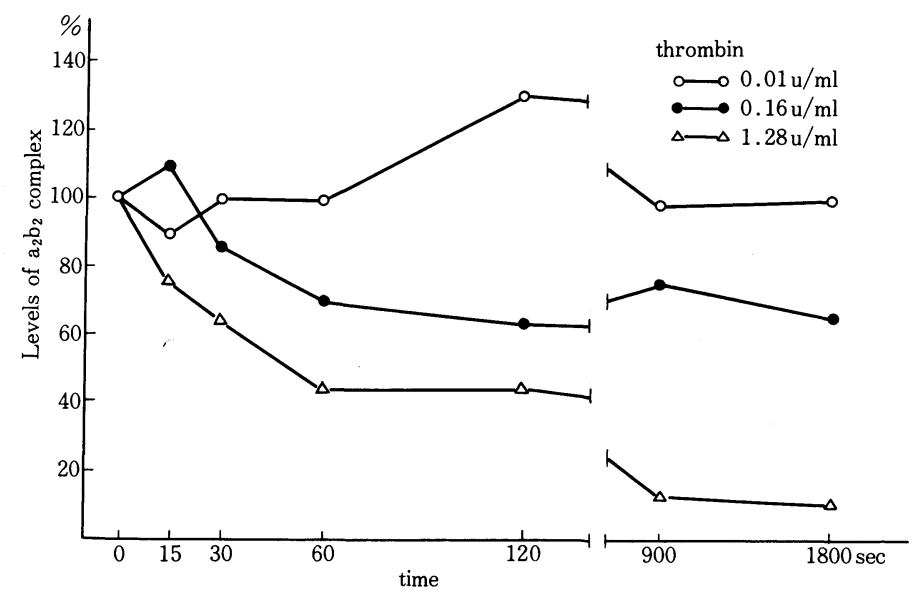

困 7 脱フィブリノゲン血漿へのトロンビン添加によるXIII因子 $\mathrm{a}_{2} \mathrm{~b}_{2}$ 複合体の解離

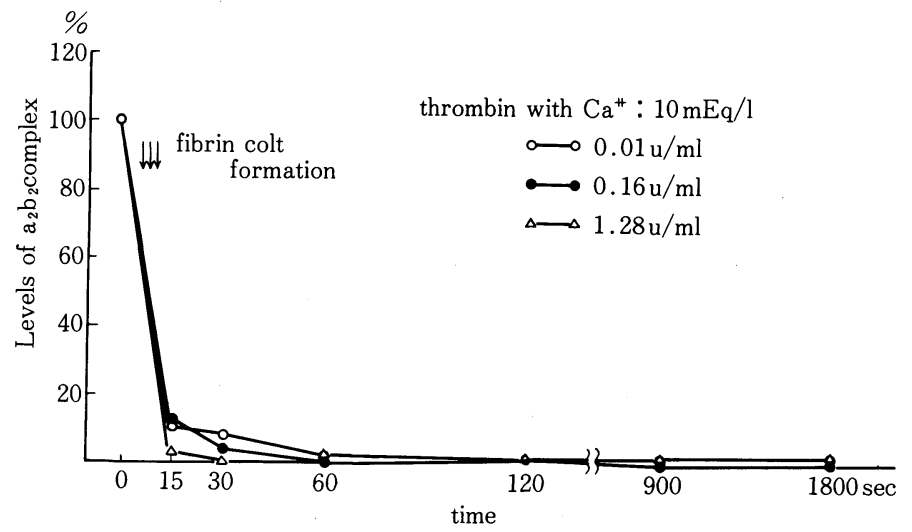

困 8 正常血漿へのトロンビン，カルシウム添加によるXIII因子 $\mathrm{a}_{2} \mathrm{~b}_{2}$ 複合体の解離

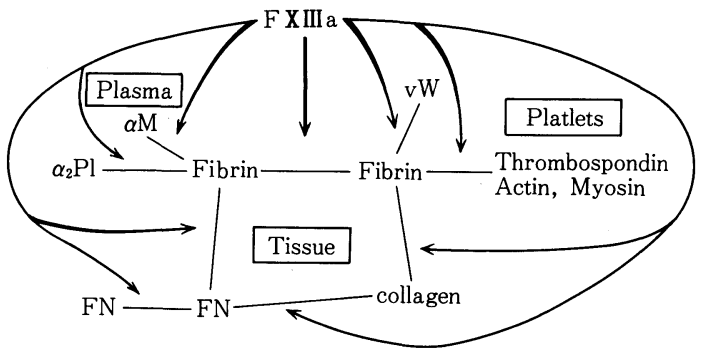

圀 $9 \mathrm{XIII}_{\mathrm{a}}$ 因子の基質の種々相

ブリンは種々の物質と交叉架橋することが出来ること から, 病態に応じて様々な止血血栓を生成しうること が示唆される。

3. 血友病における止血血栓

a. 血友病血フィブリン塊の重合異常

出血性素因の代表的疾患である血友病について，そ
の止血血栓中のフィブリン重合の病態は血友病におけ る易出血性の原因として重要な位置を占めているもの であり，フィブリン血栓の安定性に深く影響する。そ こで吾々はフィブリン血栓異常の実験的モデルとして 血友病血漿にカルシウムを添加してフィブリン塊を作 ると共に, フィブリン・モノマー自身抽びフィブリ ンに交叉架橋する諸物質をアイソトープで標識して, その重合量を観察した。

まず，正常および血友病血漿に ${ }^{131}$ I 標識フィブリノ ゲンと ${ }^{125} \mathrm{I}$ 標識 von Willebrand 因子を添加してカル シウム再加によるフィブリン塊を作り, ついで還元 SDS ポリアクリラマイドゲル電気泳動をフィブリン 塊について行い, そのゲルを $1.5 \mathrm{~mm}$ 間隔でスライスし て $\gamma$-カウンターによる $\gamma$ 線計測を行うと, 図10に示さ れるようにフィブリン形成18時間後の von Willebrand 因子のフィブリン塊中への交叉架橋による重合 


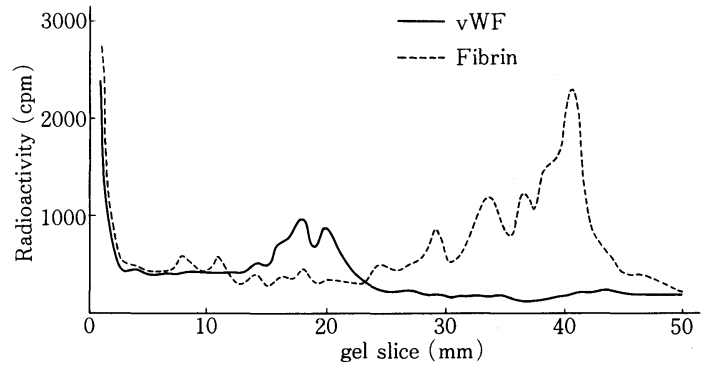

図 10 血友病A血墏よりのフィブリン塊中にみられ るvon Willebrand因子の重合異常（フィブリン形成 18 時間後)

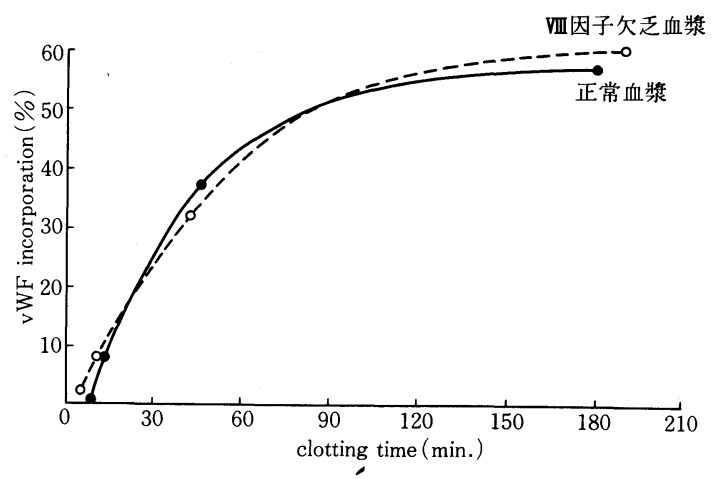

困 11 フィブリン塊へのvon Willebrand因子重合量 と凝固時間の相関

量は $20 \%$ に及び，正常血のフィブリンヘの von Willebrand 因子の重合量 $1 \%$ より明らかに増加している (羽田ら, 1986) ${ }^{9}$. また, その重合部位は $\alpha$-ポリマーの 中間部にみられる。このことは血漿と血清の間でvon Willebrand 因子の濃度差が正常血液ではみられない のに反し，血友病 A 血では血墏に比して血清中では明 かに減少していることとも関連があると思われる（羽 田ら, 1982) ${ }^{10)}$.

血友病血漿にはトロンビンの希釈列を正常血漿には ヒルジンを添加して凝固時間を変化させ, von Willebrand 因子のフィブリンへの重合量を観察すると， 正 常血漿，血友病血漿ともに凝固時間の延長に従って von Willebrand 因子の重合量が増加する傾向を示し た（図11）。このことは恐らく凝固時間の変化が von Willebrand 因子のフィブリンへの重合量を調節する 上で重要な機序であることを示唆している（羽田ら， 1986) ${ }^{11)}$

ついで $\alpha_{2}$ プラスミン・インヒビター $\left(\alpha_{2} \mathrm{PI}\right)$ のフィ ブリン・モノマーへの重合を観察すると，ヒトの ${ }^{125} \mathrm{I}$ 標

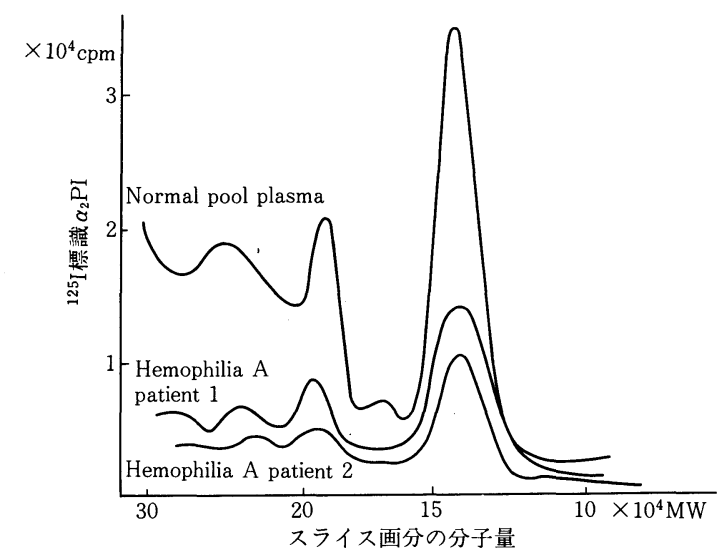

図 12 フィブリン $\alpha$-polymemへの $\alpha_{2}$ PIのcrosslink

識 $\alpha_{2} \mathrm{PI}$ を被検血漿に添加してカルシウム再加凝固 1 時間後にフィブリン塊について還元 SDS ポリアクリ ラマイドゲル電気泳動を行い,ゲルを $1.5 \mathrm{~mm}$ 間隔でス ライスして放射活性を計測すると，正常血漿を検体と した場合のフィブリン塊への $\alpha_{2}$ PI の取り込みは $\alpha$-ポ リマーにのみ起り，その重合量は約 $9 \%$ にぶが，血 友病 $\mathrm{A}$ 血漿 2 症例を検体とした時の凝固 1 時間後の フィブリン塊中の $\alpha_{2} \mathrm{PI}$ 重合量は約 $3 \%$ に減少してい る(図12).

b. 血友病に扣ける止血血栓の UK 溶解性と弾性強 度

正常血漿 $(n=10)$ と血友病 $\mathrm{A}$ 血漿 $(\mathrm{n}=2) 0.1 \mathrm{ml}$ に ついて，カルシウム再加凝固後にウロキナーゼ（1000 単位 $/ \mathrm{ml}) 0.2 \mathrm{ml}$ を上層して, フィブリン塊の溶解時間 を測ると, 血友病 A 血の溶解時間は正常域内に存在す るが，やや低值傾向を示した。しかもVIII因子濃縮製剤 750 単位を同一患者 $(n=2)$ に輸注して30分後に再測定 を行うと, 溶解時間は両症例とも延長する傾向を示し た。この成績は血友病 $\mathrm{A}$ 患者へのVIII因子輸注によっ て, フィブリンへの $\alpha_{2}$ PI の重合も正常化されること を示唆している（図13）。

さらに, ${ }^{125} \mathrm{I}$ 標識フィブロネクチンを用いて, フィブ リンへの重合量をカルシウム再加フィブリン塊の還元 SDS ポリアクリラマイドゲル電気泳動によって観察

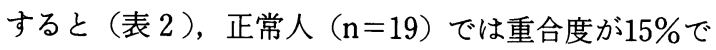

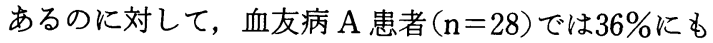
増加している(羽田ら，1985) ${ }^{11}$. McDonagh ら $(1985)^{12)}$ によると, フィブロネクチンのフィブリンヘ の重合度はフィブリン塊の溶解剤（5n 尿素， $1 \%$ monochloro-acetic acid など）による溶解性に影響し 


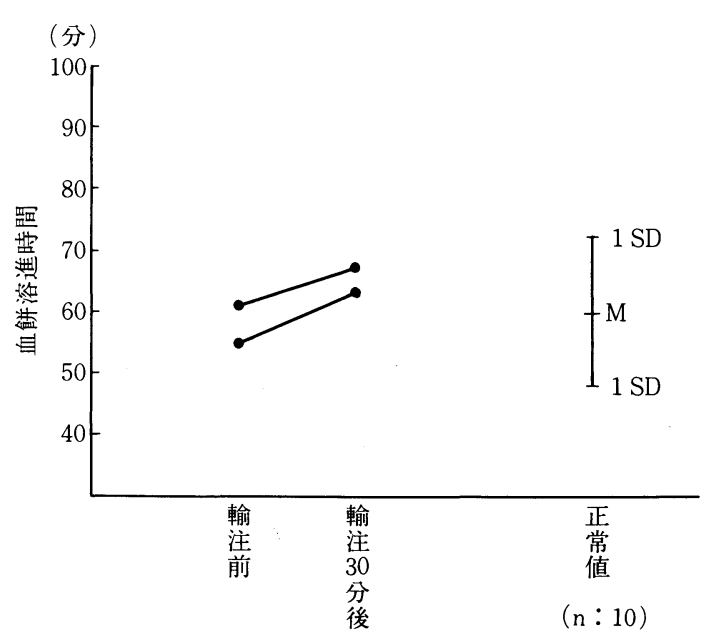

図 13 血友病の線溶へのVIII因子輸注の影響

表 2 フィブリン塊への $\alpha_{2} \mathrm{PI}, \mathrm{FN}, \mathrm{vWF}$ の crosslink 量

\begin{tabular}{c|c|c|c}
\hline & $\alpha_{2} \mathrm{PI}$ & $\mathrm{FN}$ & $\mathrm{vWF}$ \\
\hline 正 常 & $9 \%$ & $15 \%$ & $1 \%$ \\
\hline 血友病 & $3 \%$ & $36 \%$ & $20 \%$ \\
\hline
\end{tabular}

表 3 血友病 $\mathrm{A}$ 患者の Thrombelastgram

\begin{tabular}{c|c|c|l}
\hline 血友病症例(全血液) & $\mathrm{r}$ & $\mathrm{k}$ & $\mathrm{ma}$ \\
\hline 1 & $58 \mathrm{~min}$ & $48 \mathrm{~min}$ & $53 \mathrm{~mm}$ \\
2 & 143 & 61 & 32 \\
3 & 112 & 28 & 65 \\
4 & 42 & 39 & 43 \\
5 & 94 & 145 & 42 \\
6 & 94 & 100 & 40 \\
7 & 110 & 29 & 62 \\
8 & 44 & 26 & 40 \\
9 & 105 & 40 & 61 \\
\hline
\end{tabular}

血友病 $\mathrm{A}$ 患者の $\mathrm{ma}$ 平均値 $\mathrm{M} \pm \mathrm{SD}=48.7 \pm 11.8$

(正常者の $\mathrm{ma}$ 平均値 $\mathrm{M} \pm \mathrm{SD}=54.0 \pm 4.0$ )

ており，フィブロネクチン重合度が50\%近くになると 部分溶解が起きることを認めており，フィブロネクチ ン重合度の増加はフィブリン塊の溶解剤に対する抵抗 性を減弱すると述べている。すなわち，血友病の線溶 に招ける易溶性は単にフィブリン塊への $\alpha_{2} \mathrm{PI}$ の重合 量が減少しているためのみでなく，フィブロネクチン の重合量の増加も影響していることを示唆している。

また，血友病A患者 $(n=9)$ についてトロンボェス トグラムを検査してみると, 表 3 のごとく凝固時間に
関係すると, $\mathrm{k}$ は全例とも延長を示すが, 血餅の弾性強 度を示す ma（maimum elastisty of thrombus）は症 例によってやや区々であるが, 血友病 9 症例の平均值 $(\mathrm{M} \pm \mathrm{SD})$ は $48.7 \pm 11.8 \mathrm{~mm}$ であって, 正常人の平均 $54.0 \pm 4.0 \mathrm{~mm}$ より低く, 血友病 $\mathrm{A}$ 患者の血餅の弾性 は低下していることが示唆される。

上述のごとく血友病患者の血餅または, フィブリン 塊について，線溶にたいする抵抗性が減弱しており， また TEG の極大弾性度の低下傾向を示していること は血友病の止血血栓の構造に異常があり，その結果と して検査所見にもフィブリン塊に脆弱性が認められ, 臨床的には易出血性であり, 出血性素因の一因となっ ている. 基本的にはフィブリン重合の異常が構造物と しての止血血栓の機能を障害していると言える。さら に重合異常をもたらす基礎には血友病に㨟けるトロン ビン生成不全が存在していると共に XIII 因子の血小 板よりの放出とその活性化に対する機能不全が関与し ているものと思われる。

\section{おわりに}

止血異常の原因として止血血栓内におけるフィブリ ン重合の異常が認められ, その成因に血小板または血 漿凝固因子の欠損があげられた場合には，その欠損因 子を補充することが治療の基本であり, 通常は輸血あ るいは血液製剤の輸注による補充療法が行われる。そ の結果, 病的な止血機序は是正されるが, 是正の段階 としてはトロンビン生成の正常化と二次的な血小板機 能の是正についで止血血栓内フィブリン重合の正常化 を来して, 全体としての止血の機序は回復するに至る.

しかし, 頻回の輸血, 輸注にさいして重大な副作用 が注目されている。輸血の副作用は，1）ウィルス感染, 2）免度異常，3）抗体発生に集約されるが，ウィルス 感染については既に肝炎ウィルスの予防と治療に拉け る難治性は久しく議論されて来た所であるが，最近， HTLVのI型およびIII型 (HIV) ウィルスの感染こと に後者による後天性免疫低下症候群 (AIDS) の発症が 注目され，その国内侵入に対する急速な対策が望まれ ている.

対策の 1 つに recobinand 製剤の開発があり, 現在, 止血異常に対する製剂としてのVIII因子 recombinant 製剤の完成が近い。この種の製剤はヒト血液を原料と するものではなく, biotechnologyによる工場生産で あることから製品管理が確実であって, ウィルス感染 を防止する手段として役立つものと思われる.ささに 血友病のように長期頻回の輸注をうけた患者の $30 \%$ 以 
上に非ウィルス性と思われる後天性免疫低下状態がみ られるが, その原因を反復する aloantigen の侵襲によ るものと考劣るならば, recombinant 製剂中には輸注 目的以外の物質は可及的に除去されており, aloantigen の侵襲をも回避でさる可能性が期待され る.しかし, 補充物質にたいする抗体の発生について はその影響は未知であり, 現在は血友病患者の約 $5 \% に$ 抗体発生をみているが, recombinant 製剂使用後の推 移について注目する要のあるものと思われる。

本報告は止血異常の原因として止血血栓とくにフィ ブリン重合の構築異常について述べ，かつ血小板 XIII 因子の放出についても触れた。

本講演の司会の労をとられた村上省三会長に深謝すると 共に, 協力を扔しまなかった臨床病理学教室の諸氏に感謝 する.

\section{文献}

1) Niewiarowski, S., et al.: Fibrionogen interaction with platelet receptors. Ann. N.Y. Acad. Sci., 408: 536-554, 1983.

2) Hoyer, L.W.: The critical role of the factor VIII/von Willebrand factor complex in hemostasis. 第35回日本輸血学会総会 (招待講演) 1987.

3）小池克昌：XIII 因子 a-subunit, b-subunit 㧍よび $\mathrm{a}_{2} \mathrm{~b}_{2}$ complex の ELISA による測定とその応用. 東京医大誌, 45 : 363-374, 1987.

4）山田享弘：Batroxobin に上る線溶発現の解析, $と<に$ Des A fibrin polymer $と \alpha_{2}$ plasmin inhibitor の架橋形成について。東京医大誌，44：
1067-1077, 1986.

5) Okada, M. and Brombäck, B.: Factors in fluencing fibrin gel structure studies by flow measurement. Ann. New York Acad. Sci., 408: 233-253, 1983.

6) Horwitz B.H., Varadi, A. and Scherga, H.A. : Localization of a fibrin $\gamma$-chain polymerization site within segment Thr-374 to Glu-396 of human fibrinogen. Proc. Natl. Acad. Sci. U.S. A., 81 : 5980-5984, 1984.

7) Landano, A.P. and Doolittle, R.F.: Studies on synthetic peptides that bind to fibrinogen and prevent fibrin polymerization. Biochemistry, 19 : 1013-1019, 1980.

8）福田 稔：フィブリン分解物のフィブリン重合阻 害に関する研究. 東京医大誌，44：1043-1053, 1986.

9) Hada, M., et al.: Covalent crosslinking of von Willebrand factor to fibrin. Blood, 68 : 95-101, 1986.

10) Hada, M., et al.: Possible crosslinking of factor VIII related antigen to fibrin by factor XIII in delayed coagulation process. Thromb. Research., 25(1/2) : 163-168, 1982.

11) Hada, M., McDonagh, J. and Kaminski, M.: Plasma fibronectin and fibrin formation. Plasma Fibronectin, ed. McDonagh, J., Marcel Dekker Inc., New York and Basel, p. 121-148, 1985.

12) McDonagh, J.: 同上. 